\author{
Katarzyna Kopaczyńska-Pieczniak \\ Maria Curie-Skłodowska University in Lublin, Poland \\ ORCID: 0000-0002-1805-1856 \\ katarzyna.kopaczynska-pieczniak@lublin.pl
}

\title{
Defects in the Undertaking as an Object of Legal Transaction
}

\author{
Wady przedsiębiorstwa jako przedmiotu czynności prawnej
}

\section{ABSTRACT}

The article is of a scientific and research nature and contains the results of a research project conducted within the area of Polish civil law and commercial law. The aim of the research is to define the concept of "defect of the undertaking" subject to a legal transaction and to identify the relationship between the defect of the undertaking and the defects of its individual assets. It is not only of a theoretical but also practical significance to carry out an analysis of this issue, given the possibility of making an undertaking an independent object of legal transactions. An important issue is a distinction between a defect of the undertaking as an object of legal transaction, a defect in the right to the undertaking or rights to individual assets thereof. The main thesis boils down to the statement that the defect of the undertaking is a specific construct, different from the defect of its individual assets and independent of their defects. It can exist in a situation where no asset is affected by such a defect. The purpose of the research is to build the concept of "defect of the undertaking" and to demonstrate the relationship between such concept and the characteristics which make up its essence in terms of organisation, purpose and functionality, taking into account the type of the legal transaction concerned. The purpose of these deliberations is also to examine the possibility of classification of defects of the undertaking under provisions defining the incompatibility with the contract of the legal good covered by the transaction. The research is complemented by a list of types of liability for defects of the undertaking and rights correlated with this liability.

Keywords: undertaking; defect of the undertaking; legal transaction; independent object of legal transactions

CORRESPONDENCE ADDRESS: Katarzyna Kopaczyńska-Pieczniak, PhD, Dr. Habil., Full Professor, Maria Curie-Skłodowska University (Lublin), Faculty of Law and Administration, Institute of Law, Plac Marii Curie-Skłodowskiej 5, 20-031 Lublin, Poland. 


\section{INTRODUCTION}

The article aims to analyse issues related to defects in an undertaking being an object of a legal transaction. The undertaking understood in objective terms may be considered a separate object of legal transactions. In particular, it may be disposed of or granted to another person for use and for obtaining profits from it. A transfer of such a set of assets entails a question about understanding and assessment of its defects. The particular elements that need clarification are: the concept of defect in the undertaking, distinction of types of defect by which the undertaking may be affected, especially the distinction between physical defects and legal defects, and their classification as manifestations of certain irregularities affecting the undertaking. An important issue is also the assessment of the defects in the context of the essence of the undertaking as an object of a legal transaction, and thus the effect of their existence on the finding that the act concerns an undertaking. In this context, there is also a question of separating the defects of various assets of the undertaking which may be regarded as defects of the undertaking as a whole from those which do not influence the classification of the undertaking as affected by a defect. Examination of these issues requires the use of the legal dogmatic method. The issue of the undertaking and transactions concerning it is widely discussed by scholars in the field, while the concept of defects of the undertaking has not yet been the subject of a separate publication.

\section{ESSENCE OF THE UNDERTAKING AS AN OBJECT OF A LEGAL TRANSACTION}

An undertaking in the objective sense constitutes a special object of legal transactions. It is understood as an organised set of intangible and tangible assets intended for conducting business activity (Article $55^{1}$ of the Polish Civil Code ${ }^{1}$ ). It is characterised by the fact that it includes property rights (assets), i.e. components of property, while it does not include liabilities related to its operation. An important role is played here by intangible assets, such as in particular the reputation or clientele. ${ }^{2}$ Characteristically, the Code includes concessions, licences and permits, i.e. rights arising from administrative decisions, among the assets of the undertaking. ${ }^{3}$

\footnotetext{
1 Act of 23 April 1964 - Civil Code (consolidated text, Journal of Laws 2020, item 1740), hereinafter: CC.

2 M. Poźniak-Niedzielska, Zbycie przedsiębiorstwa $w$ świetle zmian $w$ kodeksie cywilnym, "Państwo i Prawo" 1991, no. 6, p. 34.

3 E.K. Czech, Koncesje i zezwolenia jako sktadniki przedsiębiorstwa, "Przegląd Prawa Handlowego" 2006, no. 5, p. 46; S. Dudzik, Zbycie przedsiębiorstwa a sukcesja praw i obowiazków wynikajacych z decyzji administracyjnych, "Państwo i Prawo" 1994, no. 7-8, p. 39; Z. Gawlik,
} 
Moreover, the undertaking is of an organised nature, which means that its assets are functionally interconnected and form a certain whole. It also has a purposeful character, as it is intended to pursue a business activity. This approach determines the fact that the undertaking, as a basis for the pursuit of a business activity, may, as a rule, belong to entities carrying out such activity, regardless of whether it constitutes the primary or secondary object of their activities.

The term "undertaking" in the objective sense is often defined as a set of property items and rights. ${ }^{4}$ Examples of its components are listed in Article $55^{1}$ $\mathrm{CC}$, but the composition of undertaking in the objective sense may be defined in two aspects: formal and material. In the formal perspective, an undertaking is in fact a set of rights to tangible and intangible assets, vested in a given entity. The definition included in Article $55^{1} \mathrm{CC}$ is not very precise from this point of view, because on the one hand it mentions the objects of rights, such as business name of the undertaking or its trade secrets, and on the other hand it points to rights as its assets, such as the ownership of real estate or movable property. On the other hand, in the material aspect, an undertaking is a set of items (tangible goods) and intangible goods, which are objects of rights constituting part of the undertaking, as well as rights for which their object cannot be distinguished (e.g., receivables).

The statutory vision of the undertaking does not determine whether it is the object of a special right (right to the undertaking) or whether it is a set of separate rights (universitas iuris). ${ }^{5}$ However, irrespective of the qualification from that point of view, the rules expressly provide for the possibility of making the undertaking an independent object of trading, by pointing to the admissibility of the legal act con-

Przedsiębiorstwo jako przedmiot obrotu a prawa wynikajace z decyzji administracyjnych, [in:] Wspótczesne problemy prawa handlowego. Ksiegga jubileuszowa dedykowana Prof. dr hab. Marii Poźniak-Niedzielskiej, ed. A. Kidyba, R. Skubisz, Kraków 2007, p. 85.

4 In particular, see J. Frąckowiak, Instytucje prawa handlowego w kodeksie cywilnym, "Rejent" 2003, no. 6, p. 21.

5 A. Wolter, J. Ignatowicz, K. Stefaniuk, Prawo cywilne. Zarys części ogólnej, Warszawa 2018, pp. 303-304; W.J. Katner, [in:] System Prawa Prywatnego, vol. 7: Prawo zobowiazań - część szczegółowa, ed. J. Rajski, Warszawa 2018, p. 55; J. Preussner-Zamorska, Konstrukcja prawa do przedsiębiorstwa i jej konsekwencje w świetle nowej regulacji prawnej, "Rejent" 1992, no. 2, p. 31 ff. On the legal nature of the undertaking, see M. Habdas, Przedsiębiorstwo w znaczeniu przedmiotowym, "Kwartalnik Prawa Prywatnego" 2002, no. 2, p. 334; T. Komosa, J. Tropaczyńska, Charakter prawny przedsiębiorstwa, "Przegląd Prawa Handlowego" 1996, no. 8, p. 29 ff.; P. Pełczyński, Charakter prawny przedsiębiorstwa w znaczeniu przedmiotowym, "Rejent" 1998, no. 1, p. 71; M. Poźniak-Niedzielska, Pojęcie przedsiębiorstwa a jego majątek, "Annales Universitatis Mariae Curie-Skłodowska" 1982, no. 8, p. 130; J. Widło, Przedsiębiorstwo w świetle zmian kodeksu cywilnego, "Monitor Prawniczy" 2004, no. 1, p. 10; E. Gniewek, [in:] Kodeks cywilny. Komentarz, eds. E. Gniewek, P. Machnikowski, Warszawa 2013, p. 129. See also resolution of the Supreme Court of 8 March 2006, III CZP 105/05, OSNC 2006, no. 10, item 159; judgement of the Supreme Court of 13 May 2004, III SK 39/04, OSNC 2005, no. 6, item 89; judgement of the Supreme Court of 3 December 2009, II CSK 215/09, Legalis; judgement of the Appellate Court in Katowice of 7 March 2014, I ACa 1175/13, LEX no. 1466784. 
cerning the undertaking (Article $55^{2} \mathrm{CC}$ ). ${ }^{6}$ Such an act may concern the undertaking as a whole, but not necessarily in all cases. In accordance with Article $55^{2} \mathrm{CC}$, that act covers everything which forms part of an undertaking, but other situation may result from the content of the legal act or from specific legal provisions. The limits of admissible exemptions, whether by the willingness of the parties to a contract of sale of the undertaking or by operation of law, are determined by two essential factors: the objective factor and functional one. The objective aspect is based on the definition of undertaking and is expressed in that, despite the exclusions, the transaction still covers the same undertaking, i.e. a complex of property rights, organised and intended for the pursuit of economic activities. The functional aspect is that the undertaking being sold should be capable of carrying out the previous activity, which means that its function is continued. ${ }^{7}$ On the other hand, the value of the set of assets being sold compared to the value of the whole undertaking is not the criterion determining whether the transaction covers the undertaking. ${ }^{8}$

Therefore, when it comes to a legal transaction concerning an undertaking, it is necessary to distinguish between an act concerning all the elements of the undertaking and one which covers the undertaking as a whole. In the first case, the matter covered by the transaction is an undertaking comprising all its constituent elements. On the other hand, in the second case, the object of the transaction is the undertaking as a whole, which may include both all the assets which make up the undertaking and the relevant part thereof, but which determines that the transaction covers the undertaking (Article $552^{2} \mathrm{CC}$ ). Consequently, an undertaking "as a whole" does not have to be a "whole" undertaking.

\section{LEGAL TRANSACTIONS CONCERNING THE UNDERTAKING}

The issue of defects of the undertaking and the liability for them is closely related to the performance of a legal transaction relating to the undertaking and the emergence of a specific legal relationship based on it. In particular, it may be a transaction resulting in a disposal of the undertaking or granting it to another person for use and to earn profits. The disposal of an undertaking may take place

6 On transactions covering undertakings, see E. Norek, Przedsiębiorstwo jako przedmiot obrotu gospodarczego, Warszawa 1997, passim; M. Bednarek, Przedsiębiorstwo jako przedmiot czynności prawnych - spory doktrynalne z perspektywy praktyki obrotu, "Studia Prawnicze" 2009, no. 3, p. 47.

7 See S. Buczkowski, Glosa do wyroku SN z 10 stycznia 1972 r., I CR 359/71, OSPiKA 1972, no. 12; judgement of the Supreme Court of 29 January 2009, V CSK 294/08, Legalis; judgement of the Supreme Court of 15 November 2010, I CSK 703/09, Legalis.

8 Judgement of the Supreme Administrative Court of 6 October 1995, SA/Gd 1959/94, "Prawo Gospodarcze" 1996, no. 3, item 30; judgement of the Voivodeship Administrative Court in Wrocław of 6 June 2008, I SA/Wr 335/08, unpublished. 
under a contract of sale (Article $535 \mathrm{CC}$ ), donation (Article $888 \mathrm{CC}$ ), exchange (Article $603 \mathrm{CC}$ ), or a partnership agreement resulting in the undertaking constituting a contribution to the partnership (Article $860 \mathrm{CC}$, Article 3 of the Code of Commercial Partnerships and Companies $\left.{ }^{9}\right) .{ }^{10}$ The granting of the undertaking for use and collection of benefits may take place primarily on the basis of a lease agreement (Article $693 \mathrm{CC}$ ).

In the event of a disposal, the assets of the undertaking, all of them or with appropriate exclusions, are transferred to another entity under single legal act (uno $a c t u$ ). Recognition of an undertaking as a set of rights means that from the juridical point of view, an act aimed at disposal of the undertaking is a set of such actions relating to its individual assets ${ }^{11}$ considered as a whole, and carried out on the basis of a single legal event pursuant to Article $55^{2} \mathrm{CC}$. Consequently, it should be considered a specific form of a set of singular successions, ${ }^{12}$ but deemed by the law a universal succession. On the other hand, assuming the existence of the subjective right to an undertaking, the object of such a legal transaction is one property right. If the undertaking is granted for use and collecting benefits from it, two models of such acts can also be considered depending on the adopted legal concept of undertaking: as a set of activities establishing the right to lease, performed as part of a single legal event, or as an act relating to the undertaking as an object of a subjective right. ${ }^{13}$ Since the transaction concerns the undertaking as a whole, its assets do not have to be listed in the content of the act, and it is sufficient to indicate the elements that individualise the undertaking (e.g., name, location). ${ }^{14}$

At the same time, individual assets of the undertaking, do not lose their separateness through the fact of belonging to it, and therefore may also be traded independently of the undertaking.

The purpose and effect of the disposal of an undertaking is to transfer it to the acquiring party, who should be able to exercise all the rights that result from hold-

9 Act of 15 September 2000 - Code of Commercial Partnerships and Companies (consolidated text, Journal of Laws 2020, item 1526), hereinafter: CCPC.

10 The term "disposal of the undertaking" (Polish: zbycie przedsiębiorstwa) used by Article $75^{1}$ CC should be understood as a transfer of the undertaking to another entity. See E. Norek, op. cit., p. 126. Regarding the subject of disposal of an undertaking, see also M. Wilejczyk, Zbycie przedsiębiorstwa, Wrocław 2004, p. 137; J. Widło, Dzierżawa i użytkowanie przedsiębiorstwa, "Nowy Przegląd Notarialny" 2003, no. 2, p. 76.

${ }_{11}$ As in by J. Skąpski, [in:] System Prawa Cywilnego, vol. 3, part 2: Prawo zobowiązań-część szczegółowa, ed. S. Grzybowski, Wrocław 1976, p. 44.

${ }_{12}$ M. Habdas, op. cit., p. 1008.

13 See J. Krzyżanowski, [in:] J. Bielski, J. Ignatowicz, J. Pietrzykowski, Z. Resich, Kodeks cywilny. Komentarz, vol. 2, Warszawa 1972, p. 1504. The author adopted the concept of a lease of the right to the undertaking.

${ }_{14}$ Z. Gawlik, [in:] Kodeks cywilny. Komentarz, vol. 1: Cześć ogólna, ed. A. Kidyba, Warszawa 2012, p. 301. 
ing the undertaking. The purpose of the granting for use is to allow the lessee (as a dependent possessor) to hold the undertaking and to use it and collect the profits it generates. All in all, the acquiring party or user of the undertaking is interested in using such a set of assets for its intended purpose and in collecting the proceeds from it. The undertaking should therefore be fit for the purpose for which such a set of assets is used, have the features and general characteristics of an undertaking of such type or listed individually in the content of the transaction, correspond to the obligations of the disposer or the party granting the undertaking for use. Therefore, the transfer or granting the undertaking for use, which does not meet the required criteria, may give rise to liability for the defects of both its individual elements and the defects of the undertaking as a whole.

\section{THE MEANING OF THE TERM “DEFECT IN THE UNDERTAKING”}

When constructing the term "defect in the undertaking", reference should be made to the legal provisions defining the concept of "defect". Of relevance in this respect are the provisions on statutory warranty for defects in the item sold, the essence of which, in accordance with Article $556 \mathrm{CC}$ is manifested in that the seller is liable to the buyer if the item sold has a physical or legal defect.

The application of the provisions on statutory warranty for defects to the disposal of an undertaking results from the norms governing transactions resulting in the undertaking disposal. As regards the contract of sale, the legal basis is Article $535 \mathrm{ff}$. CC and Article $555 \mathrm{CC}$, according to which the provisions on the sale of tangible assets also apply mutatis mutandis to the sale of energy, rights and water. ${ }^{15}$ The statutory warranty also applies for the disposal of an undertaking under a contract of exchange (Article $556 \mathrm{ff}$. CC in conjunction with Article $603 \mathrm{CC}$ ).

In the case of contribution of an undertaking to a civil-law partnership, the application mutatis mutandis of the provisions on statutory warranty relates to contribution of tangible property (Article $862 \mathrm{CC}$ ), however, pursuant to Article 555 $\mathrm{CC}$, this rule may be applied mutatis mutandis also to other rights contributed as a contribution in kind to the partnership. In commercial partnerships, the issue of the application of statutory warranty regulations in the event of making by a partner a contribution in kind with defects is an issue that raises divergent opinions among scholars in the field. ${ }^{16}$ They result from the lack of a reference in the wording of

15 The application of the provisions on statutory warranty mutatis mutandis to an undertaking is pointed out by Włodyka, M. Spyra, [in:] System Prawa Handlowego, vol. 5A: Prawo umów handlowych, ed. M. Stec, Warszawa 2020, p. 912.

${ }^{16}$ It is pointed out that there is no legal basis for the application of the provisions on statutory warranty for defects. See K. Kopaczyńska-Pieczniak, [in:] System Prawa Handlowego, vol. 5B: Prawo 
Article $49 \S 1$ CCPC to the application of the provisions on sale also in relation to defects of the item transferred as a contribution. ${ }^{17}$

The concept of "defect" is also referred to in the regulations concerning special statutory warranties in legal relationships other than sale, in particular the liability of the donor in the situation when the donated item has defects (Article 892 CC) or liability for defects of the object of lease applicable to the lease agreement (Article 694 in conjunction with Article 664 CC). In the context of these regulations, the term "defect" should be understood by analogy, similarly as within the scope of the provisions on statutory warranty in case of sale, but with taking into account the differences between these types of contracts. ${ }^{18}$ The division into physical and legal defects remains valid.

The term "defect" is also used in the regulations governing the liability of a company shareholder who made a contribution in-kind with defects (Article 14 $\S 2$ CCPC), and it seems justified to apply mutatis mutandis to the concept of defect the provisions of Article $556 \mathrm{ff}$. CC, according to the provision of Article 2 CCPC. ${ }^{19}$

umów handlowych, ed. M. Stec, Warszawa 2020, p. 430; W. Pyzioł, [in:] Kodeks spótek handlowych. Komentarz, ed. W. Pyzioł, Warszawa 2008, p. 116; T. Siemiątkowski, R. Potrzeszcz, [in:] Kodeks spótek handlowych. Komentarz, eds. T. Siemiątkowski, R. Potrzeszcz, vol. 1, Warszawa 2010, p. 345; K. Wręczycka, Wniesienie nieruchomości na własność do spółek osobowych, "Rejent" 2004, no. 9, pp. 116-117; A. Baranowska, Odpowiedzialność za wady fizyczne i prawne wkładów rzeczowych w spótkach osobowych, "Prawo Spółek" 2003, no. 6, p. 28. The application of the provisions on statutory warranty is supported by A. Kidyba, [in:] Kodeks spótek handlowych. Komentarz, ed. A. Kidyba, vol. 1, Warszawa 2017, p. 269; K. Kruczalak, [in:] Kodeks spółek handlowych. Komentarz, ed. K. Kruczalak, Warszawa 2001, p. 94; S. Sołtysiński, [in:] S. Sołtysiński, A. Szajkowski, A. Szumański, J. Szwaja, Kodeks spótek handlowych. Komentarz, vol. 1, Warszawa 2012, p. 515; J.A. Strzępka, E. Zielińska, [in:] Kodeks spótek handlowych. Komentarz, ed. J.A. Strzępka, Warszawa 2015, p. 138; R. Stefanicki, Odpowiedzialność z tytułu rękojmi za wady fizyczne wkładu rzeczowego w spółce jawnej (waga problemu), [in:] Kodeks spótek handlowych po pięciu latach, ed. J. Frąckowiak, Wrocław 2006, p. 453.

17 This is so because this norm provides for the application of the provisions on sales mutatis mutandis to the obligation of the contributing partner to transfer the ownership of the contribution to the partnership/company and to the risk of accidental loss of the object of the transfer. Article 103 of the Regulation of the President of the Republic of Poland of 27 June 1934 - Commercial Code (Journal of Laws 1934, no. 57, item 502, as amended), previously in force, expressly provided for the application of the provision on sales also to the liability of the partner under statutory warranty.

${ }_{18}$ For defects in the object of tenancy, see H. Ciepła, [in:] Kodeks cywilny. Komentarz, ed. J. Gudowski, vol. 3, part 2, Warszawa 2013, p. 401; J. Jezioro, [in:] Kodeks cywilny. Komentarz, eds. E. Gniewek, P. Machnikowski, Warszawa 2017, p. 1182; J. Panowicz-Lipska, [in:] System Prawa Prywatnego, vol. 8: Prawo zobowiazań - część szczegółowa, ed. J. Panowicz-Lipska, Warszawa 2011, p. 31.

19 See, i.a., M. Michalski [in:] Kodeks spótek handlowych. Komentarz, ed. A. Kidyba, vol. 1, p. 184; W. Popiołek, [in:] Kodeks spółek handlowych. Komentarz, ed. W. Pyzioł, p. 47; M. Rodzynkiewicz, Kodeks spółek handlowych. Komentarz, Warszawa 2005, p. 38; A. Szumański, [in:] S. Sołtysiński, A. Szajkowski, A. Szumański, J. Szwaja, op. cit., p. 287. Cf. judgement of the Appellate Court in Warsaw of 9 June 2010 (I ACa 21/10, LEX no. 1120088), according to which the concept of defect used in Article $14 \S 2$ CCPC is not identical to such concept and protection means provided for in provisions on sale. 
These regulations do not define the term "defect". In general, under the provisions on statutory warranty, the term can be understood as each negative feature of the object of a legal transaction (sale, donation, exchange, contribution to the partnership/company, lease), which limits or excludes the possibility of achieving the purpose of the contract concerned, as well as the general socio-economic purpose of the obligation resulting from such contract. ${ }^{20}$ The negative nature of this feature is expressed in the fact that in each event, both in the case of a physical defect and a legal defect, it reduces the value of the object of the legal transaction, which in a mutual agreement should be assessed from the point of view of the equivalence of performances of the parties.

Since an undertaking is a set of rights, in particular concerning tangible assets or other assets (e.g., intellectual property), as well as rights whose object cannot be identified (e.g., claims), it is necessary to distinguish between defects of the undertaking and defects which may apply to particular assets thereof. However, in any event, a defect is a feature of the object of a legal transaction. ${ }^{21}$ Therefore, irrespective of the concept of legal transaction concerning an undertaking and the view on validity of the right to the undertaking, namely both when we accept that it is a legal transaction relating to the right to the undertaking and when we adopt that it concerns a set of rights which are the assets constituting the undertaking, the defects relate to the undertaking which is (verba legis - Article $55^{2} \mathrm{CC}$ ) an object of such transaction. In each case, the defect concerns an organised and functioning set of tangible and intangible items and rights as a certain whole, intended for the pursuit of business activities and thus for the production of certain revenues. However, it does not seem reasonable to reduce a defect in the undertaking to the right to the undertaking or, alternatively, to a set of property rights constituting the undertaking. ${ }^{22} \mathrm{~A}$ legal transaction consists in the transfer or encumbrance of such a right or rights, and the object of that transaction is in any event the undertaking as a specific category of a set of assets. Therefore, the disposal of the undertaking or encumbering it does not constitute a disposal or encumbrance of a right, in particular its sale cannot be regarded as a sale of the right, and the lease of the undertaking is not a lease of the right.

As a result, a "defect in the undertaking" is a specific type of defect. This is a kind of negative feature relating to an organised set of assets intended for the pursuit of business activity as a certain economic whole. Therefore, it should be assessed taking into account primarily the features that determine the essence of the undertaking as a specific object of trading (organisation, purposefulness, and func-

${ }^{20}$ See K. Kopaczyńska-Pieczniak, op. cit., p. 840 ff.

${ }^{21}$ Judgement of the Appellate Court in Warsaw of 28 September 2016, I ACa 1096/16, LEX no. 2171245.

${ }^{22}$ Such a view is represented by E. Norek, op. cit., p. 193. 
tionality). In view of the above, it is expressed in irregularities in the organisation or functioning of such an undertaking and in making it difficult or impossible to use it for business activities. Both the undertaking as an object of legal transaction and its individual assets may be affected by a physical defect and a legal defect. ${ }^{23}$ As a consequence, both a physical defect and a legal defect restrict or prevent the proper use of the undertaking. The essence of the defect in an undertaking is the fact that it may exist despite the fact that none of the undertaking's assets, whether tangible or intangible, is affected by the defect. In the context of the essence of the undertaking, the lack of features determining the recognition of certain assets as an undertaking cannot be considered a defect. If there is no element of their organisation, or they are not a "set" or are not fit for business purposes, then the object of the legal transaction cannot be regarded as an undertaking. As a consequence, such irregularities cannot be considered a defect in the undertaking.

\section{PHYSICAL DEFECT IN AN UNDERTAKING}

When referring the definition of physical defect set out in Article $556^{1} \S 1 \mathrm{CC}$ to an undertaking, such defect must be regarded as consisting in the incompatibility of the undertaking being sold with the contract. At the same time, this provision lists examples of individual manifestations of such non-compliance. The definition of physical defect resulting from Article $556^{1} \S 1 \mathrm{CC}$ was therefore structured in two stages. Such approach to a defect means that the definition is open-ended, since it makes it possible to consider as a physical defect also other cases of the object of contract having no expected characteristics which do not fall within any of the manifestations of non-conformity stated in the law. ${ }^{24}$ The wording of that provision relates to a contract of sale and parties thereto, but it should also be referred to the disposal of the undertaking based on other acts in law.

Among the manifestations listed in Article $556^{1} \S 1 \mathrm{CC}$, a physical defect in the undertaking as a whole may be the lack of properties which the undertaking should have because of the purpose specified in the agreement or resulting from the cir-

${ }^{23}$ As proposed also by S. Włodyka, M. Spyra, op. cit., p. 913. Differently E. Norek (op. cit., p. 193) according to whom the statutory warranty for physical defects of an undertaking as a whole cannot be taken into account because the undertaking is disposed of as a a certain property right. Also T. Mróz ([in:] System Prawa Prywatnego, vol. 9: Prawo zobowiazań - umowy nienazwane, ed. W.J. Katner, Warszawa 2015, p. 912) limits the undertaking seller's liability under the warranty only to legal defects.

${ }^{24}$ See J. Jezioro, op. cit., pp. 1176-1177. On defects that are not defined in legal regulations, see P. Stec, [in:] Ustawa o prawach konsumenta. Kodeks cywilny (wyciag). Komentarz, eds. B. Kaczmarek-Templin, P. Stec, D. Szostek, Warszawa 2014, p. 406 ff. Other perspective: A. Brzozowski ([in:] Kodeks cywilny. Komentarz, ed. K. Pietrzykowski, vol. 2, Warszawa 2015, p. 309), supporting the previous interpretation which assumes a closed catalogue of defects. 
cumstances or its intended use (Article $556^{1} \S 1$ (1) CC). The properties of the legal transaction object, whose absence makes it affected by a physical defect, include a wide range of features, determining its quality, usefulness or applicability. Any lack of the expected properties is subject to assessment under this provision, taking into account two criteria, namely: the type of the object of sale, in this case the undertaking, and the purpose of acquisition. Type may be understood as a category covering undertakings aimed at meeting specific needs, capable of performing with their use a specific type of economic activity. Thus, it includes a group of undertakings having certain features in common, typical for them. On the other hand, the purpose of the acquisition of a particular undertaking may be specified directly in the agreement or may result from the circumstances or its purpose. The decisive factor is the purpose of the specific transaction, assessed from the point of view of the acquiring party, thus having a subjective nature. The intention behind the acquisition of the undertaking may be specified in the agreement by including a provision pointing out the use of the set of assets intended by the acquiring party. The purpose may also result from the intended use of the undertaking. This means that the parties enter into the contract to allow the undertaking to be used by the acquiring party in a particular way. When determining the existence of such a defect, functional rather than normative-technical considerations are decisive. ${ }^{25}$ The unsuitability of the undertaking for its intended use is expressed in the fact that the acquiring entity cannot use it fully, so the undertaking cannot be used for any normal purpose it may serve, its use requires additional effort on the part of the acquiring entity, causes inconvenience or generates higher costs or does not produce the results normally associated with the proper use of an undertaking of the type in question. This type of defect takes place where the undertaking is unsuited to pursuit a specific economic activity. In particular, a trade-and-service undertaking meets the conditions for a trade activity, whereas it is not suitable for running a service activity.

Another type of non-compliance with the contract, and thus a physical defect, occurs when, pursuant to Article $556^{1} \S 1$ (2) CC, the object of sale does not have

25 A. Brzozowski, op. cit., p. 310; E. Łętowska, Glosa do wyroku SA w Warszawie z 23 lutego 2000 r., I ACa 1281/99, "Państwo i Prawo" 2000, no. 10. See also resolution of the Supreme Court of 30 December 1988, III CZP 48/88, OSNCP 1989, no. 3, item 36; judgement of the Supreme Court of 20 May 1997, II CKN 115/97, Legalis; judgement of the Supreme Court of 10 July 2002, II CKN 111/01, LEX no. 109412; judgement of the Supreme Court of 2 April 1993, I CKN 244/01, Legalis; judgement of the Supreme Court of 18 November 2003, II CK 201/02, Legalis; judgement of the Supreme Court of 9 March 2006, I CSK 147/05, “Orzecznictwo Sądów Gospodarczych” 2008, no. 4, item 28; judgement of the Supreme Court of 5 March 2010, IV CNP 76/09, Legalis; judgement of the Supreme Court of 17 April 2013, I CSK 457/12, Legalis; judegment of the Appellate Court in Białystok of 18 February 2016, I ACa 961/15, LEX no. 2002789; judgement of the Appellate Court in Kraków of 31 May 2016, I ACa 937/15, LEX no. 2053829; judgement of the Appellate Court in Kraków of 8 July 2016, I ACa 172/16, LEX no. 2081574. 
properties of which the seller has assured (dicta et promissa) the purchaser. ${ }^{26}$ The seller's assurance should be understood as his statement of knowledge of a categoric nature, certifying that the undertaking certainly has or will have certain properties. The seller is responsible for the assurances contained in the agreement, expressed orally at the conclusion of the contract, included in the name of the undertaking or those used in the advertisement. ${ }^{27}$ In particular, the assurance of participation in foreign trade, and thus an indication of the export-import nature of the undertaking, also included in the name ("export-import") in a situation where the undertaking operates only on the domestic market, may be treated as an absence of designated properties. A defect of this kind may also occur in the case of the assurances of the disposing party to the acquiring party that the undertaking is encumbered with liabilities of a certain amount if these debts significantly exceed the indicated value. It may also take the form of assurances about holding the relevant licence or concession in a situation where the proceedings in this case have just been initiated, so this right is not part of the undertaking and the undertaking cannot carry out the activity covered by the licence/concession. This type of defect may also be the lack of turnover or profit generated by the undertaking, which was assured by the disposing party. This applies to a situation where the undertaking did not generate the declared turnover or profit at the time of its disposal. However, it cannot be considered a defect when the lack of guaranteed economic result of the undertaking's activity occurs after its sale, i.e. when the undertaking is already used by the acquiring entity. ${ }^{28}$

Another manifestation of a physical defect in the undertaking, resulting from its non-compliance with the contract, is the situation when the undertaking is unfit for the purpose about which the acquiring party informed the disposing party at the conclusion of the contract, and the disposing party failed to make any objections to such purpose of the undertaking (Article 556 ${ }^{1} \S 1$ (3) CC). This applies to a situation where the acquiring party, when concluding the contract, specified to the disposing party the intended purpose for which the acquiring party acquires the undertaking, i.e. the purpose for which the latter intends to use it. The phrase "at the conclusion of the contract" means that the purpose should be made known to the disposing party in the

${ }^{26}$ E. Norek (op. cit., p. 194) classifies such a defect as a legal defect in the undertaking. The same view is shared by T. Mróz (op. cit., pp. 912-913).

27 E. Łętowska, Prawo umów konsumenckich, Warszawa 2002, p. 309; I. Byczkowska, Odpowiedzialność z tytułu rękojmi za wady rzeczy sprzedanej (wybrane zagadnienia), "Państwo i Prawo" 2000, no. 9, p. 69 ff.

${ }^{28}$ See J. Krauss, [in:] Prawo handlowe, eds. J. Okolski, M. Modrzejewska, Warszawa 2012, p. 681; E. Norek, op. cit., p. 194. See also judgement of the Voivodeship Administrative Court in Kraków of 24 July 2007 (I SA/Kr/1483/05, LEX no. 517229), according to which "in the Polish legal system, the party disposing of the undertaking is not held liable under contractual guarantee (or statutory warranty) for defects of the transferred undertaking, understood as a lack of expected turnover achieved by the undertaking acquired". 
course of activities leading to the conclusion of the contract, i.e. during negotiations, in the offer, in response to the offer or in the tender announcement. The formulation of the provision of Article 556 $\$ 1$ (3) CC, which refers to the purpose for which the disposing party did not raise any objections, seems to suggest that it concerns cases where the purpose specified by the acquiring party differs from the standard (typical) purpose of the undertaking, but remains in line with its properties. Such a situation may take place in particular when the acquiring party states the intention to use the undertaking to pursue activities of a similar nature to the current one, but not the same.

A physical defect in the undertaking may also include its release to the acquiring party in an incomplete state (Article $556^{1} \S 1$ (4) CC). In the case of a set of tangible items, a release in an incomplete state means that some of the components of the set are missing. ${ }^{29}$ Also for the disposal of an undertaking, the incompleteness of the object of sale may be expressed in the lack of individual assets of the property complex that were covered by the contract. ${ }^{30}$ This is particularly important in relation to those assets of the undertaking that determine its identity and function. The lack of such elements may raise doubts as to whether the contract concerned a specific undertaking, or only a certain set of assets unrelated to the function performed.

The types of defects mentioned as an example can also be applied by analogy to cases where an undertaking is granted for use, in particular on the basis of a lease agreement (Article 664 in conjunction with Article 694 CC). However, in such a situation, in the context of the provisions of Article $664 \S \S 1$ and 2 CC, only those irregularities which limit the suitability of the undertaking for the intended use or prevent its use are relevant in view of the purpose of the contract. Therefore, their existence corresponds to a general clause contained in Article $556^{1} \S 1$ $\mathrm{CC}$, which states that an undertaking is incompatible with a contract, since its use covered by the content thereof and which constitutes the purpose of its conclusion is restricted or impossible.

\section{LEGAL DEFECT IN AN UNDERTAKING}

The irregularity of the object of a legal transaction may concern not only its physical properties but also the legal sphere. This is why the concept of legal defect has been distinguished apart from the concept of physical defect..$^{31} \mathrm{~A}$ legal defect may relate both to a tangible property and to another object of a legal transaction. In particular, a legal defect may affect the rights covered by a contract, or a set of

29 Judgement of the Supreme Court of 18 November 2003, II CK 201/02, Legalis.

${ }^{30}$ Differently E. Norek, op. cit., p. 195; T. Mróz, op. cit., p. 943.

${ }^{31}$ For the warranty for legal defects in more detail, see M. Podrecka, Rękojmia za wady prawne rzeczy sprzedanej, Warszawa 2011, passim. 
rights such as an undertaking. The concept of legal defect is regulated in Article $556^{3}$ CC. Referring it to an undertaking as a whole, its legal defect may be manifested by the fact that the holder of rights in the undertaking is a third party and that the disposing party is not entitled to dispose of the undertaking. If we accept the view that there is a single right to an undertaking, the defect would consist in that the holder of that right is a third party. The second manifestation of a legal defect in an undertaking is encumbering it with a third party's right. This may be the case especially where the right of usufruct is established on the undertaking (Article 252 in conjunction with Article $265 \mathrm{CC}$ ) or where it is granted for use under a lease agreement (Article 693 in conjunction with Article 709 CC). The third type of legal defect is that the restriction on the use or disposal of an undertaking results from a decision or ruling of the competent authority. In this case, the source of the defect is the existence of an appropriate act of public authority, in particular a decision or ruling issued by a public authority or administrative body, as well as a judgement issued by a court, e.g. an injunctive relief established in the course of judicial proceedings $\mathrm{s}^{32}$ and an attachment in the course of enforcement proceedings $\mathrm{s}^{33}$ or the establishment of a compulsory administration of an undertaking (Article $1064^{1} \mathrm{ff}$. of the Code of Civil Procedure).

Moreover, in the event of a transfer of the right, the disposing party is also responsible for its existence. In such a situation, the legal defect may consist in that the right to be transferred does not exist. In the case of an undertaking, this type of legal defect may exceptionally occur where the assets of the undertaking are only rights and titles, in particular claims, concessions, or shareholdings in companies. The defect in an undertaking could be that these rights actually do not exist. On the other hand, a situation where there is no undertaking understood as an organised property complex intended for the pursuit of an economic activity and the disposing party is actually entitled to ownership of immovable property, such as land and a factory building built on it, does not constitute a legal defect. ${ }^{34}$

${ }^{32}$ See judgement of the Appellate Court in Katowice of 14 November 2003, I ACa 524/03, LEX no. 175278 .

33 J. Skąpski (op. cit., p. 130) and E. Habryn-Chojnacka ([in:] Kodeks cywilny. Komentarz, ed. M. Gutowski, vol. 2, Warszawa 2016, p. 413) consider an attachment during enforcement proceedings as a manifestation of encumberance with a third-party right.

${ }^{34}$ Differently E. Norek, op. cit., p. 193; S. Włodyka, M. Spyra, op. cit., p. 913. 


\section{A DEFECT IN AN ASSET OF THE UNDERTAKING AND A DEFECT IN THE UNDERTAKING}

On the backdrop of the construct of defect in an undertaking, an important issue is distinguishing it from defects of its individual assets. The finding of defects in specific assets of the undertaking does not constitute a sufficient basis to recognize that the undertaking as a whole is defective. ${ }^{35}$ However, both in the case of physical and legal defects a question arises how to qualify defects relating to the basic assets of the undertaking, deciding about its identity and functions (referred to as essential assets $\left.{ }^{36}\right)$. It seems that such a defect, especially a major one, can be considered as a defect in the undertaking as an object of the contract, as it reduces its value and usability, and results in that it cannot be used as intended. In particular, such a character may have a defect in the form of unfitness for the intended purpose of a production line due to the lack of properties that it should have due to its purpose or a defect in the form of a mortgage established on a property forming a basic asset of the undertaking. ${ }^{37}$ In these cases, the defect relates to a particular asset, but for the entity acquiring the undertaking, it may constitute a circumstance that prevents or significantly hinders its use, and thus performance of the undertaking. Also in a situation where defects concern individual assets of the undertaking, but all or most of them are affected, which significantly limits the possibility of using the undertaking in accordance with its intended purpose, it can be considered that such an irregularity is a defect in the undertaking as a whole.

At the same time, the existence of a defect in the undertaking does not depend on the existence of a defect in its asset or assets. An undertaking as an organised property complex may be affected by a defect expressing in the wrong organisation, or an incorrect arrangement of its assets that are not affected by defects. As a consequence, on the one hand, the existence of a defect in an asset of the undertaking does not mean the existence of a defect in the undertaking, and on the other hand, we may distinguish among defects of the undertaking those, which are a derivative of the existence of defects of its asset or assets, and those that exist regardless of whether its individual assets are defective or not.

${ }^{35}$ See judgement of the Supreme Court of 24 January 2019 (II CSK 762/17, LEX no. 2618456), according to which in the case of the sale of a multi-element set of tangible items identified as to their kind, with heterogeneous composition and characteristics of individual items, the finding of defects in the elements of the set does not automatically allow finding the defectiveness of the whole set.

${ }^{36}$ As in E. Norek, op. cit., p. 193; T. Mróz, op. cit., p. 943; S. Włodyka, M. Spyra, op. cit., p. 914.

${ }^{37}$ Cf. E. Norek, op. cit., p. 194. 


\section{TYPES OF LIABILITY FOR DEFECTS OF THE UNDERTAKING}

When an undertaking is disposed of, the disposing party's liability for defects arises. First of all, the disposing party can be held liable under the statutory warranty, which is imposed on it by operation of law (ex lege).$^{38}$ It is independent of the disposing party's fault, its knowledge of the defect ${ }^{39}$ or the fact of contributing to its occurrence in any way. The statutory warranty is a special type of liability due to its objective and absolute character. ${ }^{40}$ Moreover, it is based on the risk principle and has an absolute character. ${ }^{41}$ Its sufficient basis is the existence of a defect in the tangible item concerned. ${ }^{42}$ The statutory warranty is also characterised by a limited scope of subject matter, because it is a liability for defects of tangible items. The rights vested in the acquiring party under the statutory warranty for defects of the undertaking include the claim for rectification of the defect (Article $561 \S 1$ $\mathrm{CC}$ ), as well as rights under a unilateral-modification clause to reduce the price and to withdraw from the agreement (Article $560 \S 1 \mathrm{CC}$ ), but the acquiring party may not withdraw from the contract if the defect is of a minor nature. Due to the individualized nature of any undertaking, in case of defects in it, the claim for replacement of the object of contract with a defect-free one (Article $561 \S 1 \mathrm{CC}$ ) is unlikely to apply.

In the case of a donation under Article $892 \mathrm{CC}$, liability under the statutory warranty for defects takes on the form of liability for damages and includes the obligation to compensate for damage caused to the donee by the donor who, being aware of the defects, failed to notify the donee in a timely manner.

The lease of an undertaking affected by a defect gives rise to the lessor's liability under the statutory warranty, with the lessee's rights being differentiated depend-

${ }^{38}$ M. Nesterowicz, [in:] Kodeks cywilny. Komentarz, ed. J. Winiarz, vol. 1, Warszawa 1989, p. 556.

39 Judgement of the Appellate Court in Katowice of 5 March 2009, V ACa 484/08, OSAKat. 2009, no. 9, item 4.

40 E. Łętowska, Prawo umów..., p. 379; A. Brzozowski, op. cit., pp. 304-305; S. Buczkowski, [in:] J. Bielski, J. Ignatowicz, J. Pietrzykowski, Z. Resich, op. cit., p. 1299; Z. Gawlik, [in:] Kodeks cywilny. Komentarz, vol. 3: Część szczególna, ed. A. Kidyba, Warszawa 2014, pp. 102-103; J. Jezioro, op. cit., p. 1174; C. Żuławska, [in:] Kodeks cywilny. Komentarz, ed. J. Gudowski, vol. 3, part 2, pp. 60-61. See also judgement of the Appellate Court in Warsaw of 9 June 2010, I ACa 21/10, LEX no. 1120088; judgement of the Supreme Court of 28 November 2007, V CNP 124/07, Legalis; judgement of the Appellate Court in Katowice of 5 March 2009, V ACa 484/08, OSAKat. 2009, no. 9, item 4; judgement of the Appellate Court in Kraków of 22 June 2016, I ACa 153/16, LEX no. 2108546; judgement of the Appellate Court in Warsaw of 6 September 2016, VI ACa 503/14, LEX no. 2149595.

${ }^{41}$ J. Jezioro, op. cit., p. 1174; W.J. Kocot, Glosa do uchwaty SN z 30 maja 1996 r., III CZP 42/96, "Przegląd Prawa Handlowego" 1997, no. 1, p. 29; J. Skąpski, op. cit., p. 1180.

42 A. Brzozowski, op. cit., p. 305; E. Habryn-Chojnacka, op. cit., p. 394. See also judgement of the Supreme Court of 27 January 2017, V CSK 161/16, LEX no. 2269113; judgement of the Appellate Court in Warsaw of 27 March 2013, VI ACa 1269/12, Legalis; judgement of the Appellate Court in Białystok of 23 December 2014, I ACa 601/14, Legalis. 
ing on the relevance of the defect to the usefulness of the object of the contract. If the undertaking is affected by a defect which limits its usefulness for the use as agreed, then the lessee can demand reduction of rent for the duration of the defect (Article $664 \S 1$ in conjunction with Article 694 CC). On the other hand, if the defect makes the use of the property impossible as provided for in the agreement and the lessor does not remove such defects or they cannot be removed, then the lessee can terminate the agreement without notice (Article $664 \S 2$ in conjunction with Article 694 CC).

The existence of defects in the undertaking covered by a legal transaction may also constitute grounds for contractual liability, i.e. liability for failure to perform or improper performance of the obligation. In the case of reciprocal agreements, the provisions of Article $487 \mathrm{ff}$. CC apply, and in matters not regulated therein, they are governed by general provisions on contractual liability contained in Article $471 \mathrm{ff}$. CC. In this case, a party may demand under general rules a compensation for damage constituting a normal consequence of the existence of such defects, unless they were caused by circumstances for which the other party is responsible.

The tort liability cannot be ruled out either (Article $415 \mathrm{ff}$. CC). This liability regime will apply where defects of the undertaking are a result of misconduct of a party to the transaction. It may involve deliberate damage or destruction of individual assets of the undertaking. If these assets play a key role in the undertaking and are crucial for their use as intended, then the damage can be assessed in relation to the whole undertaking. In such a case, the offender's liability for damages covers damage caused by the improper functioning of the undertaking or the impossibility of performing its functions. If the act or omission which results in a damage simultaneously constitutes a failure to perform or improper performance of an existing obligation between the parties, then this does not exclude the claim for compensation for damage resulting from a tort, unless otherwise stated in the agreement (Article $443 \mathrm{CC}$ ).

In so doing, a party has the option of choosing the regime of liability under which its claims are based and of using statutory warranty or seeking compensation under contractual or tort liability. It also has the possibility to seek claims for damages on a general basis, alongside the exercise of rights under statutory warranty. ${ }^{43}$

On the other hand, contributing a defective undertaking as an in-kind contribution to a company generates in a shareholder of a limited liability company

${ }^{43}$ A. Brzozowski, op. cit., p. 304; judgement of the Appellate Court in Szczecin of 25 April 2013, I ACa 176/13, Legalis; judgement of the Appellate Court in Szczecin of 7 May 2015, I ACa 30/15, LEX no. 1785316; judgement of the Appellate Court in Warsaw of 15 March 2018, I ACa 2148/16, LEX no. 2514581; judgement of the Appellate Court in Wrocław of 6 July 2018, I AGa 257/18, LEX no. 2679028; judgement of the Appellate Court in Kraków of 23 November 2018, I ACa 357/18, LEX no. 2699133. 
or a joint-stock company a compensatory liability, expressed in the obligation to compensate the capital company for the difference between the value specified in the articles of association and the selling value of the contribution (Article $14 \S 2$ CCPC). The liability provided for in Article $14 \S 2$ CCPC is a strict compensatory liability, referred to as absolute liability, as the shareholder bears it regardless of his fault or knowledge of the defect, as well as regardless of whether it was caused through his behaviour or not. ${ }^{44}$ It is also independent of whether the company has suffered damage as a result of the defective contribution. ${ }^{45}$ Due to the autonomous nature of the regulation contained in Article $14 \S 2$ CCPC, the provisions on statutory warranty may be applied mutatis mutandis under Article 2 CCPC to a limited extent. ${ }^{46}$ The shareholder's compensation to the company will in principle take the form of a cash payment, although it may also be considered permissible to compensate the difference in value by the shareholder fulfilling one of the non-cash performances provided for in the provisions on the statutory warranty, ${ }^{47}$ in particular by rectifying the defect or replacing the item with a non-defective one (Article 561 $\S 1 \mathrm{CC}$ in conjunction with Article $2 \mathrm{CCPC})^{48}$. The articles of association may also specify other rights of the company towards the shareholder who made the defective contribution. They may take the form of the shareholder's obligation to rectify the damage or pay a contractual penalty, or the company's right to compulsorily redeem shares held by this shareholder. ${ }^{49}$

${ }^{44}$ Its specific character is pointed out by T. Siemiątkowski (Odpowiedzialność cywilnoprawna w spótkach kapitałowych, Warszawa 2007, p. 143 ff.).

${ }^{45}$ Cf. judgement of the Supreme Court of 11 December 2002, I CKN 1315/00, LEX no. 75349. Although there is no express provision, it should be assumed that a shareholder may not be exempted from this liability in the articles of association. See J.P. Naworski, [in:] Kodeks spótek handlowych. Komentarz, eds. T. Siemiątkowski, R. Potrzeszcz, vol. 1, p. 154.

46 A. Szumański, op. cit., pp. 288-289; E. Skibińska, Kodeks spótek handlowych, Warszawa 2003, p. 147. Cf. judgement of the Appellate Court in Warsaw of 12 April 2000 (I ACa 1202/99), concerning the liability for a defect in a contribution under the provisions of the Commercial Code.

${ }^{47}$ A. Szumański, op. cit., p. $168 \mathrm{ff}$.

${ }^{48}$ However, a reduction in the value of the shares acquired by the shareholder (referring to a reduction in the price - Article $560 \S 1 \mathrm{CC}$ ), which would require the redemption of part of the shares of the shareholder, must be considered inadmissible. Moreover, it is inadmissible to withdraw from the articles of association (referring to Article $560 \S 1 \mathrm{CC}$ ), which does not apply to articles of association as incompatible with their nature.

${ }^{49}$ See, i.a., A. Kidyba, op. cit., p. 119; M. Michalski, op. cit., p. 185; J.P. Naworski, op. cit., p. 155; W. Popiołek, op. cit., p. 47; A. Szumański, op. cit., p. 291. 


\section{CONCLUSIONS}

An undertaking in the objective sense constitutes a special object of legal transactions. The composition of an undertaking so understood may be defined in two aspects: formal and material. In the formal perspective, an undertaking is in fact composed of rights to tangible and intangible assets vested in a given entity. On the other hand, in the material aspect, an undertaking is a set of items (tangible goods) and intangible goods, which are objects of rights constituting part of the undertaking, as well as rights for which their object cannot be distinguished (e.g., receivables). Speaking of a legal transaction concerning an undertaking, it is necessary to distinguish between an act concerning all the elements of the undertaking and one which covers the undertaking as a whole.

Generally, the term "defect" can be understood as each negative feature of the object of a legal transaction (sale, donation, exchange, contribution to the partnership/company, lease), which limits or excludes the possibility of achieving the purpose of the contract concerned, as well as the general socio-economic purpose of the obligation resulting from such contract. In each case, a defect in the undertaking relates to an organised and functioning set of tangible and intangible goods and rights as a certain whole, intended for the pursuit of business activities and thus for the production of certain revenues, and not the right to the undertaking, or alternatively to a collection of assets constituting the undertaking. A "defect in the undertaking" is a certain negative feature related to the undertaking as a certain business whole. An undertaking may be affected by a physical or legal defect.

The essence of the defect in the undertaking is the fact that it may exist despite the fact that none of the undertaking's assets, whether tangible or intangible, is affected by the defect. Furthermore, the finding of defects in specific assets of the undertaking does not constitute a sufficient basis to consider defective the undertaking as a whole.

\section{REFERENCES}

\section{Literature}

Baranowska A., Odpowiedzialność za wady fizyczne i prawne wkładów rzeczowych w spótkach osobowych, "Prawo Spółek" 2003, no. 6.

Bednarek M., Przedsiębiorstwo jako przedmiot czynności prawnych-spory doktrynalne z perspektywy praktyki obrotu, "Studia Prawnicze" 2009, no. 3.

Brzozowski A., [in:] Kodeks cywilny. Komentarz, ed. K. Pietrzykowski, vol. 2, Warszawa 2015.

Buczkowski S., [in:] J. Bielski, J. Ignatowicz, J. Pietrzykowski, Z. Resich, Kodeks cywilny. Komentarz, vol. 2, Warszawa 1972.

Buczkowski S., Glosa do wyroku SN z 10 stycznia 1972 r., I CR 359/71, OSPiKA 1972, no. 12. 
Byczkowska I., Odpowiedzialność z tytulu rękojmi za wady rzeczy sprzedanej (wybrane zagadnienia), "Państwo i Prawo" 2000, no. 9.

Ciepła H., [in:] Kodeks cywilny. Komentarz, ed. J. Gudowski, vol. 3, part 2, Warszawa 2013.

Czech E.K., Koncesje i zezwolenia jako sktadniki przedsiębiorstwa, "Przegląd Prawa Handlowego" 2006, no. 5 .

Dudzik S., Zbycie przedsiębiorstwa a sukcesja praw i obowiązków wynikajacych z decyzji administracyjnych, "Państwo i Prawo" 1994, no. 7-8.

Frąckowiak J., Instytucje prawa handlowego w kodeksie cywilnym, "Rejent" 2003, no. 6.

Gawlik Z., [in:] Kodeks cywilny. Komentarz, vol. 1: Cześć ogólna, ed. A. Kidyba, Warszawa 2012.

Gawlik Z., [in:] Kodeks cywilny. Komentarz, vol. 3: Częśś szczególna, ed. A. Kidyba, Warszawa 2014.

Gawlik Z., Przedsiębiorstwo jako przedmiot obrotu a prawa wynikajace z decyzji administracyjnych, [in:] Wspótczesne problemy prawa handlowego. Księga jubileuszowa dedykowana Prof. dr hab. Marii Poźniak-Niedzielskiej, ed. A. Kidyba, R. Skubisz, Kraków 2007.

Gniewek E., [in:] Kodeks cywilny. Komentarz, eds. E. Gniewek, P. Machnikowski, Warszawa 2013.

Habdas M., Przedsiębiorstwo w znaczeniu przedmiotowym, "Kwartalnik Prawa Prywatnego" 2002, no. 2.

Habryn-Chojnacka E., [in:] Kodeks cywilny. Komentarz, ed. M. Gutowski, vol. 2, Warszawa 2016.

Jezioro J., [in:] Kodeks cywilny. Komentarz, eds. E. Gniewek, P. Machnikowski, Warszawa 2017.

Katner W.J., [in:] System Prawa Prywatnego, vol. 7: Prawo zobowiąań - część szczególowa, eds. J. Rajski, Warszawa 2018.

Kidyba A., [in:] Kodeks spótek handlowych. Komentarz, ed. A. Kidyba, vol. 1, Warszawa 2017.

Kocot W.J., Glosa do uchwaty SN z 30 maja 1996 r., III CZP 42/96, "Przegląd Prawa Handlowego" 1997, no. 1.

Komosa T., Tropaczyńska J., Charakter prawny przedsiębiorstwa, "Przegląd Prawa Handlowego" 1996, no. 8 .

Kopaczyńska-Pieczniak K., [in:] System Prawa Handlowego, vol. 5B: Prawo umów handlowych, ed. M. Stec, Warszawa 2020.

Kruczalak K., [in:] Kodeks spółek handlowych. Komentarz, ed. K. Kruczalak, Warszawa 2001.

Krauss J., [in:] Prawo handlowe, eds. J. Okolski, M. Modrzejewska, Warszawa 2012.

Krzyżanowski J., [in:] J. Bielski, J. Ignatowicz, J. Pietrzykowski, Z. Resich, Kodeks cywilny. Komentarz, vol. 2, Warszawa 1972.

Łętowska E., Glosa do wyroku SA w Warszawie z 23 lutego 2000 r., I ACa 1281/99, "Państwo i Prawo" 2000, no. 10.

Łętowska E., Prawo umów konsumenckich, Warszawa 2002.

Michalski M, [in:] Kodeks spółek handlowych. Komentarz, ed. A. Kidyba, vol. 1, Warszawa 2017.

Mróz T., [in:] System Prawa Prywatnego, vol. 9: Prawo zobowiąań - umowy nienazwane, ed. W.J. Katner, Warszawa 2015.

Naworski J.P., [in:] Kodeks spółek handlowych. Komentarz, eds. T. Siemiątkowski, R. Potrzeszcz, vol. 1, Warszawa 2010.

Nesterowicz M., [in:] Kodeks cywilny. Komentarz, ed. J. Winiarz, vol. 1, Warszawa 1989.

Norek E., Przedsiębiorstwo jako przedmiot obrotu gospodarczego, Warszawa 1997.

Panowicz-Lipska J., [in:] System Prawa Prywatnego, vol. 8: Prawo zobowiązań-część szczegółowa, ed. J. Panowicz-Lipska, Warszawa 2011.

Pełczyński P., Charakter prawny przedsiębiorstwa w znaczeniu przedmiotowym, "Rejent" 1998, no. 1.

Podrecka M., Rękojmia za wady prawne rzeczy sprzedanej, Warszawa 2011.

Popiołek W., [in:] Kodeks spótek handlowych. Komentarz, ed. W. Pyzioł, Warszawa 2008.

Poźniak-Niedzielska M., Pojęcie przedsiębiorstwa a jego majątek, "Annales Universitatis Mariae Curie-Skłodowska" 1982, no. 8. 
Poźniak-Niedzielska M., Zbycie przedsiębiorstwa w świetle zmian w kodeksie cywilnym, "Państwo i Prawo" 1991, no. 6.

Preussner-Zamorska J., Konstrukcja prawa do przedsiębiorstwa i jej konsekwencje w świetle nowej regulacji prawnej, "Rejent" 1992, no. 2.

Pyzioł W., [in:] Kodeks spótek handlowych. Komentarz, ed. W. Pyzioł, Warszawa 2008.

Rodzynkiewicz M., Kodeks spótek handlowych. Komentarz, Warszawa 2005.

Siemiątkowski T., Odpowiedzialność cywilnoprawna w spótkach kapitałowych, Warszawa 2007.

Siemiątkowski T., Potrzeszcz R., [in:] Kodeks spótek handlowych. Komentarz, eds. T. Siemiątkowski, R. Potrzeszcz, vol. 1, Warszawa 2010.

Skąpski J., [in:] System Prawa Cywilnego, vol. 3, part 2: Prawo zobowiazań - część szczegółowa, ed. S. Grzybowski, Wrocław 1976.

Skibińska E., Kodeks spólek handlowych, Warszawa 2003.

Sołtysiński S., [in:] S. Sołtysiński, A. Szajkowski, A. Szumański, J. Szwaja, Kodeks spółek handlowych. Komentarz, vol. 1, Warszawa 2012.

Stec P., [in:] Ustawa o prawach konsumenta. Kodeks cywilny (wyciag). Komentarz, eds. B. Kaczmarek-Templin, P. Stec, D. Szostek, Warszawa 2014.

Stefanicki R., Odpowiedzialność z tytułu rękojmi za wady fizyczne wkładu rzeczowego w spótce jawnej (waga problemu), [in:] Kodeks spótek handlowych po pięciu latach, ed. J. Frąckowiak, Wrocław 2006.

Strzępka J.A., Zielińska E., [in:] Kodeks spółek handlowych. Komentarz, ed. J.A. Strzępka, Warszawa 2015.

Szumański A., [in:] S. Sołtysiński, A. Szajkowski, A. Szumański, J. Szwaja, Kodeks spótek handlowych. Komentarz, vol. 1, Warszawa 2012.

Widło J., Dzierżawa i użytkowanie przedsiębiorstwa, "Nowy Przegląd Notarialny" 2003, no. 2.

Widło J., Przedsiębiorstwo w świetle zmian kodeksu cywilnego, "Monitor Prawniczy" 2004, no. 1.

Wilejczyk M., Zbycie przedsiębiorstwa, Wrocław 2004.

Włodyka S., Spyra M., [in:] System Prawa Handlowego, vol. 5A: Prawo umów handlowych, ed. M. Stec, Warszawa 2020.

Wolter A., Ignatowicz J., Stefaniuk K., Prawo cywilne. Zarys części ogólnej, Warszawa 2018.

Wręczycka K., Wniesienie nieruchomości na własność do spółek osobowych, "Rejent" 2004, no. 9. Żuławska C., [in:] Kodeks cywilny. Komentarz, ed. J. Gudowski, vol. 3, part 2, Warszawa 2013.

\section{Legal acts}

Act of 23 April 1964 - Civil Code (consolidated text, Journal of Laws 2020, item 1740).

Act of 15 September 2000 - Commercial Partnerships and Companies Code (consolidated text, Journal of Laws 2020, item 1526).

Regulation of the President of the Republic of Poland of 27 June 1934 - Commercial Code (Journal of Laws 1934, no. 57, item 502, as amended).

\section{Case law}

Judgement of the Appellate Court in Warsaw of 12 April 2000, I ACa 1202/99.

Judgement of the Appellate Court in Katowice of 14 November 2003, I ACa 524/03, LEX no. 175278.

Judgement of the Appellate Court in Katowice of 5 March 2009, V ACa 484/08, OSAKat. 2009, no. 9 , item 4 .

Judgement of the Appellate Court in Warsaw of 9 June 2010, I ACa 21/10, LEX no. 1120088.

Judgement of the Appellate Court in Warsaw of 27 March 2013, VI ACa 1269/12, Legalis.

Judgement of the Appellate Court in Szczecin of 25 April 2013, I ACa 176/13, Legalis. 
Judgement of the Appellate Court in Katowice of 7 March 2014, I ACa 1175/13, LEX no. 1466784. Judgement of the Appellate Court in Białystok of 23 December 2014, I ACa 601/14, Legalis. Judgement of the Appellate Court in Szczecin of 7 May 2015, I ACa 30/15, LEX no. 1785316. Judgement of the Appellate Court in Białystok of 18 February 2016, I ACa 961/15, LEX no. 2002789. Judgement of the Appellate Court in Kraków of 31 May 2016, I ACa 937/15, LEX no. 2053829. Judgement of the Appellate Court in Kraków of 22 June 2016, I ACa 153/16, LEX no. 2108546. Judgement of the Appellate Court in Kraków of 8 July 2016, I ACa 172/16, LEX no. 2081574. Judgement of the Appellate Court in Warsaw of 6 September 2016, VI ACa 503/14, LEX no. 2149595. Judgement of the Appellate Court in Warsaw of 28 September 2016, I ACa 1096/16, LEX no. 2171245. Judgement of the Appellate Court in Warsaw of 15 March 2018, I ACa 2148/16, LEX no. 2514581. Judgement of the Appellate Court in Wrocław of 6 July 2018, I AGa 257/18, LEX no. 2679028. Judgement of the Appellate Court in Kraków of 23 November 2018, I ACa 357/18, LEX no. 2699133. Judgement of the Supreme Administrative Court of 6 October 1995, SA/Gd 1959/94, "Prawo Gospodarcze" 1996 , no. 3, item 30.

Judgement of the Supreme Court of 2 April 1993, I CKN 244/01, Legalis. Judgement of the Supreme Court of 20 May 1997, II CKN 115/97, Legalis. Judgement of the Supreme Court of 10 July 2002, II CKN 111/01, LEX no. 109412. Judgement of the Supreme Court of 11 December 2002, I CKN 1315/00, LEX no. 75349. Judgement of the Supreme Court of 18 November 2003, II CK 201/02, Legalis. Judgement of the Supreme Court of 27 November 2003, I CK 267/02, Legalis. Judgement of the Supreme Court of 13 May 2004, III SK 39/04, OSNC 2005, no. 6, item 89. Judgement of the Supreme Court of 9 March 2006, I CSK 147/05, "Orzecznictwo Sądów Gospodarczych" 2008, no. 4, item 28.

Judgement of the Supreme Court of 28 November 2007, V CNP 124/07, Legalis. Judgement of the Supreme Court of 29 January 2009, V CSK 294/08, Legalis. Judgement of the Supreme Court of 3 December 2009, II CSK 215/09, Legalis. Judgement of the Supreme Court of 5 March 2010, IV CNP 76/09, Legalis.

Judgement of the Supreme Court of 15 November 2010, I CSK 703/09, Legalis. Judgement of the Supreme Court of 17 April 2013, I CSK 457/12, Legalis.

Judgement of the Supreme Court of 27 January 2017, V CSK 161/16, LEX no. 2269113. Judgement of the Supreme Court of 24 January 2019, II CSK 762/17, LEX no. 2618456.

Judgement of the Voivodeship Administrative Court in Kraków of 24 July 2007, I SA/Kr/1483/05, LEX no. 517229.

Judgement of the Voivodeship Administrative Court in Wrocław of 6 June 2008, I SA/Wr 335/08, unpublished.

Resolution of the Supreme Court of 30 December 1988, III CZP 48/88, OSNCP 1989, no. 3, item 36. Resolution of the Supreme Court of 8 March 2006, III CZP 105/05, OSNC 2006, no. 10, item 159.

\section{ABSTRAKT}

Artykuł ma charakter naukowo-badawczy i zawiera wyniki badań prowadzonych na gruncie polskiego prawa cywilnego i handlowego. Tematem badań jest zdefiniowanie pojęcia „wada przedsiębiorstwa” będącego przedmiotem czynności prawnej, a także ustalenie zależności pomiędzy wadą przedsiębiorstwa a wadami jego poszczególnych składników. Podjęcie się analizy wskazanego zagadnienia ma znaczenie nie tylko teoretyczne, ale i praktyczne z uwagi na możliwość uczynienia z przedsiębiorstwa samodzielnego przedmiotu obrotu prawnego. Istotnym zagadnieniem jest odróżnienie wady przedsiębiorstwa jako przedmiotu czynności prawnej od wady prawa do przedsiębiorstwa czy praw do poszczególnych jego składników. Główna teza sprowadza się do stwierdzenia, że wada 
Pobrane z czasopisma Studia Iuridica Lublinensia http://studiaiuridica.umes.pl Data: 26/04/2023 16:36:49

przedsiębiorstwa jest specyficzną konstrukcją odmienną od wady poszczególnych jego składników i niezależną od ich wad. Może istnieć w sytuacji, gdy żaden składnik nie jest taką wadą dotknięty. Celem badań jest skonstruowanie pojęcia „wada przedsiębiorstwa” i wykazanie zależności pomiędzy taką wadą a cechami składającymi się na jego istotę w postaci zorganizowania, celowości oraz funkcjonalności, przy uwzględnieniu rodzaju czynności prawnej mającej za przedmiot przedsiębiorstwo. Rozważania mają też na celu zbadanie możliwości zakwalifikowania wad przedsiębiorstwa na podstawie przepisów określających przejawy niezgodności dobra będącego przedmiotem czynności prawnej z umową. Uzupełnieniem badań jest zestawienie rodzajów odpowiedzialności z tytułu wad przedsiębiorstwa i przysługujących $\mathrm{z}$ tego tytułu uprawnień.

Slowa kluczowe: przedsiębiorstwo; wada przedsiębiorstwa; czynność prawna; samodzielny przedmiot obrotu prawnego 